\title{
The Authentic Monk: A Study of 'Authenticity' within the Works of Thomas Merton
}

\author{
Lucas Lognion \\ Department of Religious Studies \\ University of Colorado Boulder
}

\begin{abstract}
:
This paper discusses the history of the concept "authenticity" within the works of Thomas Merton. During his undergraduate and graduate studies at Columbia is where he first developed a theme which would run through most of his religious writings: authenticity. By tracing this term back to his professor, Lionel Trilling, this will give us a new lens through which to view Thomas Merton's teachings. This paper will also discuss other influences to his use of "authenticity," including his prolonged exposure and affinity towards Marxism, as well as his interests in Existential writers such as Albert Camus. The discussion of authenticity in Merton's work revolves around three themes: 1) Solitude, 2) Alienation, and 3) the Absurd. The goal of this paper is to not only illustrate the history of a particular concept in Merton's work to more fully understand this Catholic monk, but will demonstrate that traditionally non-religious concepts and thinkers often influence the religious lives and experiences of mystics.
\end{abstract}

Keywords: Authenticity, Merton, Absurd, Trilling, Marx 
"On the last day of January 1915, under the sign of the Water Bearer, in a year of a great war, and down in the shadow of some French mountains on the borders of Spain, I came into the world." And so was the first sentence of what would become Thomas Merton's most well-known book, his autobiography The Seven Storey Mountain. Merton narrates the beginning of his life with the same poetic prose used to profess his love of God. The war, the mountains, the Water Bearerall symbols foreshadowing the life of the monk to come, or, depending on how you view an autobiography, the life that has already been lived. One could also ask how self-fulfilling is the symbolism given it was the author who self-consciously and retroactively embedded it into paper forever. But that is the nature of autobiographies. Truth and fiction are interwoven carefully, whether intentionally or not, to create an image of oneself. The questions then arise, does the image of oneself match one's actual self? Is one authentic?

A popular definition of authenticity is to match one's outer expression with one's inner experience. For Thomas Merton, authenticity was much more. Though, what he meant by authenticity is hard to say because his definition drew from a variety of sources. This paper will address that definition. What does Thomas Merton mean when he speaks of authenticity? What makes one authentic? For Merton, there is no clear answer; however, numerous connections can still be traced throughout his varied positions. Just like an autobiography, this paper will be a history told through self-conscious symbols of the author's choosing. By tracing the history of authenticity within the works of Merton back to Lionel Trilling, Karl Marx, and Albert Camus, and using solitude and deep self, alienation, and the Absurd as our conceptual lenses, our understanding of his use of the term will become a little less hazy. The concepts and thinkers follow a loose correlation, with Lionel Trilling correlating with solitude and the deep self, Marxism with alienation, and Camus with the Absurd. These influences and symbols will not correspond as neatly as one would wish; Marxism, for example, can be seen as influencing Merton's conception of solitude. Merton utilizes these four concepts to explain how the authentic self is one's deep self travelling towards God in solitude, fulfilling one's

\footnotetext{
1 Thomas Merton, The Seven Storey Mountain (Orlando: Harcourt, Inc., 1998), p. 3.
} 
being not by the acquisition of material goods or escaping the Absurd, but by embracing the Absurd and allowing God' grace to grant meaning in a meaningless world.

Thomas Merton's life was characterized by movement and instability. As a child, Merton followed his father, a landscape painter, often travelling between Europe and the United States. Merton spent his formative years in France and England, though mostly the latter after being enrolled in a number of boarding schools, with Oakham School being the most prominent. Oakham is where he developed his love for literature and philosophy, reading Joyce and Marx with equal gusto. In 1933, after brief travels to Rome and the United States, Merton enrolled at Cambridge University where he was eventually expelled for fathering a child out of wedlock. It is interesting to note Merton never wrote of the child, or if he did attempt to in his books, the Trappist censors would not allow it. ${ }^{2}$ After his expulsion, he enrolled at Columbia University in New York City to begin his second year of undergraduate studies in English. Merton's time at Columbia would impact his thinking more than he would know; it is here where he would study under Lionel Trilling, become an active member of the Communist Party, and receive his calling from the Catholic Church.

Thomas Merton received his bachelor's and master's degree in English from Columbia University. Though Merton never mentions literature scholar Lionel Trilling in his autobiography, instead discussing another professor Mark Van Doren, Trilling's thought still had a tremendous impact on the future monk's religious thought. ${ }^{3}$ By giving an exposition of Trilling's thoughts on sincerity and authenticity, the scholar's influence will become clear. Even though Trilling's aptly titled book Sincerity and Authenticity was published three years after Merton's death, and long after

\footnotetext{
${ }^{2}$ Merton, The Seven Storey Mountain, xxii.

${ }^{3}$ One could argue Van Doren had a larger impact on Merton, because Trilling and Merton were both his students, but that is not the position I am taking. Given the vast similarities between Trilling and Merton, this is the more pertinent influence.
} 
his studies at Columbia, it is still the proper publication to analyze the Merton's ideas given the similarity of thought. ${ }^{4}$

In Trilling's Sincerity and Authenticity, he gives an account of the rise of sincerity as a moral value in the North Atlantic and its eventual usurpation by authenticity. He first describes the idea of sincerity in modern society as the "congruence between avowal and actual feelings." Put another way, to be sincere is to say how one really feels. He traces the modern idea of sincerity back to Shakespeare's play Hamlet, where Polonius tells Laertes, "This above all: to thine own self be true.... thou canst not then be false to any man." ${ }^{6}$ The performative aspect of sincerity is evident; Laertes is not only told to be true to himself, but to be true to himself for others. There is a strong moral fiber in this concept of sincerity. One must not be true to oneself for its own sake, but for the sake of others; you are true to yourself because you should not be false to others. According to Trilling, this was the moral code of Europe for centuries and he believed the autobiography is the very definition of the moral of sincerity, since "the subject of an autobiography is... bent on revealing himself in all his truth, bent, that is to say, on demonstrating his sincerity." "7 In other words, the author is attempting to relay their true self to their audience.

The status of sincerity began to waiver when modern classical writers in the late $19^{\text {th }}$ and early $20^{\text {th }}$ centuries started to dissociate themselves from their works. For these authors, they were not "men speaking to men," speaking impersonally and without obligation to their audience. Trilling quotes T.S. Eliot in Sincerity and Authenticity saying, "The progress of an artist is a continual selfsacrifice, a continual extinction of personality."” With literature, the writer was no longer required to be sincere in their work for their work to be judged as literature.

\footnotetext{
${ }^{4}$ The goal of this paper is not to historically prove this specific work influenced Thomas Merton's religious thought, because given the dates of publication would have made it impossible, but rather it is to show a thematic similarity between Trilling's secular and Merton's religious thoughts that cannot be ignored given their past history.

${ }^{5}$ Lionel Trilling, Sincerity and Authenticity (Cambridge: Harvard University Press, 1972), p. 4.

${ }^{6}$ Ibid., 3.

7 Ibid., 25.

8 Ibid., 7.

9 Ibid.
} 
If we want to take a deontological perspective, if writers no longer had to abide by the moral obligation to be one's true self for others, then why was anyone else morally obligated to do the same? The "for others" part of sincerity, the moral obligation, was no longer a necessity; in fact, it was seen as insincere and diametrically opposed to sincerity. Being true to one's own self was seen only as a means to an end, the end being the moral obligation to perform as one's true self. The question was raised, "If one is true to one's own self for the purpose of avoiding falsehood to others, is one being truly true to one's own self?"10 This questioning helped usher in the age of authenticity, though what authenticity actually means is difficult to say.

In the latter half of Sincerity and Authenticity, Trilling juxtaposes the two concepts to highlight their differences. He argues that authenticity has "a more strenuous moral experience than 'sincerity' does, a more exigent conception of the self and of what being true to it consists in, a wider reference to the universe and man's place in it, and a less acceptant and genial view of the social circumstances of life." In other words, Trilling attributes four characteristics to the concept of authenticity: a person has more of an obligation to be authentic than they did to be sincere, a better sense of what being true to oneself means, a broadening sense of belonging to something greater than oneself, and a greater distrust or less appealing view of society in general. Trilling's definition of Authenticity is best exemplified in the works of Thomas Merton when he discusses the necessity of solitude and discovering one's deep self in God.

Solitude and the "deep self" are themes heavily used in the work of Thomas Merton and are critical for understanding his thought in relation to Lionel Trilling; take the following passage as an example:

Today more than ever we need to need to recognize that the gift of solitude is not ordered for the acquisition of strange contemplative powers, but first of all to the recovery of one's deep self, and to the renewal of an authenticity which is twisted out of shape by the

\footnotetext{
${ }^{10}$ Ibid., 9.

11 Ibid., 11.
} 
pretentious routines of a disorganized togetherness. What the world asks of the priest today is that he should be first of all a person who can give himself because he has a self to give. And indeed, we cannot give Christ if we have not found him, and we cannot find him if we cannot find ourselves. ${ }^{12}$

In other words, solitude is the beginning step to discovering "one's deep self." A person must leave the trappings of society, escape the "pretentious routines" of the worldly life in order to find the "authenticity" one is seeking. It would be a mistake to understand solitude as only physical isolation, as if the only thing one needed to do was live alone to achieve spiritual perfection. Physical isolation is part and parcel of Merton's understanding of solitude_-after all, he did live in his own hermitage on the grounds of what is supposed to be a cenobitic monastery-but interior solitude is at least equally, if not more, important. If you cannot leave society, if you have to "live in a city and work among machines," then you must find and accept the "seed of solitude planted in your soul" by God. ${ }^{13}$ It is this "gift of solitude" which leads one to one's true self.

What exactly Merton means by the "deep self" or true self is opaque, though he does give some qualifications for what to expect. The deep self is the "person" within; it is what the priest is expected to be and what he is expected to give. "Secrecy and solitude are values that belong to the very essence of personality."14 Though for Merton, one does not only find one's true self when one goes into solitude; finding one's true self is also akin to finding Christ or God. When we enter into our own solitude, we enter the "solitude of God." 15 Relating the finding of one's deep self to finding Christ does two things: first, it contextualizes the deep self, defining it within a Christian context rather than leaving it as an abstract notion; and second, it gives the person a deeper sense of self in relation to the universe, in this case allowing one a deeper relationship with a God whom Merton holds to have created him and everything around him. As with Trilling's definition of authenticity, Merton's conception of the term involves a separation from society, a deepening

\footnotetext{
12 Thomas Merton, Seeds (Boston: Shambhala, 2002), 68 - 69.

13 Ibid., 67.

${ }^{14}$ Ibid., 71.

15 Ibid., 73.
} 
sense of relationship to the universe, and a greater understanding of what the authentic self is. Where Merton departs from Trilling in his understating of authenticity is the role of obligation to others. The priest, who is supposed to find his person in solitude, is expected to give himself away to his congregation; there is a moral obligation for the person to find themselves for others. The role of obligation in the authentic self, for Merton, is an inherently social obligation. One find's oneself so one can find Christ so then one can give Christ and oneself to others. The lines between the Trilling-esque definitions of sincerity and authenticity are blurred within the works of Thomas Merton due to this obligation to others.

For Merton, solitude is the necessary means by which one is allowed to discover their deep self, their authentic self. Solitude, though, is only received by divine grace, as a gift bestowed upon you by God. This "gift of solitude" is then used to discover one's deep self. The deep self, with all of its characteristics given by Merton, aligns itself with Lionel Trilling's four-part definition of authenticity, with only one slight deviation towards sincerity in regards to the role of social obligation. In this sense, we can confidently say Merton's conceptions of solitude and the deep self are deeply influenced by Trilling's understandings of sincerity and authenticity.

Another influence to Thomas Merton's conception of authenticity is Karl Marx. ${ }^{16}$ The connection between Marx and Merton is best understood through the concept of alienation in relation to being and materiality. In Economic and Philosophical Manuscripts - this passage in particular is featured in Sincerity and Authenticity-Marx writes:

The less you eat, drink, buy books, go to the theatre or to balls, or to the public house, and the less you think, love, theorize, sing, paint, fence, etc., the more you will be able to save and the greater will become your treasure which neither moth nor dust will corrupt-

\footnotetext{
${ }^{16}$ It is well known that Merton was a member of the Communist Party; and even though he clarifies multiple times in The Seven Storey Mountain that his communist leanings were misguided attempts at finding an identity, it is still evident the ideas of early Marx influenced the monk's later thinking. A passage of Marx featured in Sincerity and Authenticity offers strong circumstantial evidence for its influence on Merton: the Marx passage was first published in 1932, only a few years before he started at Columbia, and it was of great interest to Lionel Trilling, Merton's literature professor. Merton was also a self-identified Communist at the time of publication. All of this indicates a strong likelihood that Merton had read this during his time at Columbia.
} 
your capital. The less you are, the less you express your life, the more you have, the greater your alienated life-the greater is the saving of your alienated being. Everything which the economist takes from you in the way of life and humanity, he restores to you in the form of money and wealth. ${ }^{17}$

For Marx, human life is meant to be lived, to be experienced, to enhance the feeling of what it means to be. Going to the theatre, singing, loving, painting, and thinking all of these connect one with the innermost experience of being, of what it means to be a person. It is when we are obsessed with the accumulation of material goods, obsessed with the saving of capital, obsessed with having, do we alienate ourselves from Being. The alienated life, for Marx, is one centered not just on the acquiring of money and wealth, but on believing one must need something material in order to feel, or fill, one's being. As Trilling astutely points out, Marx's emphasis on alienation is "not merely the alienation of the working class but that of human beings in general." 18

Now let us compare this with a passage from Merton:

It is precisely this illusion, that mechanical progress means human improvement, that alienates us from our own being and our own reality. It is precisely because we are convinced that our life, as such, is better if we have a better car, a better TV set, better toothpaste, etc., that we condemn and destroy our own reality and the reality of our natural resources. Technology was made for man, not man for technology. In losing touch with being and thus with God, we have fallen into a senseless idolatry of production and consumption for their own sakes. [...] The evil in the world is all of our own making, and it proceeds entirely from our ruthless, senseless, wasteful, destructive, and suicidal neglect of our own being. ${ }^{19}$

For Merton, being and God are intricately related. If one does not know one's own being, then one does not know God, and conversely, if one knows one's being, one knows God. This can be read as knowing one's authentic being. Think back to what Merton said about the relationship between one's “deep self," one's authentic self,

\footnotetext{
${ }^{17}$ Karl Marx, Early Writings (New York: McGraw-Hill, 1964), quoted in Trilling, Sincerity and Authenticity, 122.

${ }^{18}$ Ibid., 123.

${ }^{19}$ Merton, Seeds, 46.
} 
and God: "we cannot find [Christ] if we cannot find ourselves." So finding one's being is akin to finding one's authentic self because it brings one closer to God. The alienated life, for Merton, is one that is dissociated from one's being, dissociated from the closeness of God. The cause of this alienation, of this dissociation, is the belief that material objects, particularly new material objects, "a better car, a better TV set," will bring us into the fullness of our own Being, a fullness that only Christ can supply. If moving into our own fullness of being in God is the authentic life, the authentic way of being, then a life in pursuit of material goods is an inauthentic way of being.

One can see how Marx and Merton are similar: they both believe Being is key to the authentic life and the pursuit of material goods inhibits one's ability to experience the fullness of being as such. The obvious divergence of their thoughts involves the role of God. For Marx, experiencing one's being is something that comes about from our own doing, something we produce ourselves-which makes sense, because, for Marx, being and alienation are tied to those who own the means of production. One becomes alienated from one's being when one does not own what one produces. Fullness of being does not come from God, because there is no need for God, fullness comes from ourselves. This cannot be said for Merton. Fullness of being does not come from ourselves, but can only come from God. To "recognize our condition before God is itself a grace." ${ }^{20}$ If we were to attempt to gain the fullness of Being ourselves, if we were to attempt to produce ourselves, the fullness we felt "would be the result of violence and would be inauthentic." ${ }^{21}$ It would be violent and inauthentic because, for us to attempt to produce the fullness of being ourselves, we would have to actively deny and subvert the fullness we already are by the grace of God.

The third influence we can see in Thomas Merton's conception of authenticity is Albert Camus. Merton wrote many literature essays while living at the Abbey of Gethsemani, including a collection entitled, "Seven Essays on Albert Camus." Albert Camus was a French novelist in the mid-20 ${ }^{\text {th }}$ century, often

${ }^{20}$ Ibid., 84.

${ }^{21}$ Ibid., 84. 
considered to be a leading figure in the existentialist movement due to the themes deployed in such writings as The Myth of Sisyphus and, the Nobel Prize winning, The Stranger. Camus joined Jean Paul Sartre and Simone de Beauvoir in questioning the meaning of life and existence as such. Camus's greatest contribution to the existentialist movement was the concept of the Absurd. While the Absurd has been popularly conceived as a general malaise toward a modern life devoid of meaning, Camus's conception was much more nuanced.

For Camus, the Absurd is the fundamental disharmony felt between a person and the universe; more precisely, it is the disharmony between the human need for order and meaning and the complete indifference of the world to either. The Absurd is not the indifference of the universe, but our confrontation with it. As he explains, "The absurd is not in man nor in the world, but in their presence together...it is the only bond uniting them." 22 The existential unease and dread we feel when we encounter the cold, heartless world can be confronted in three ways according to Camus: physical suicide, philosophical suicide, or acceptance. ${ }^{23}$ Physical suicide in the face of absurdity is a coward's way out, according to Camus. Philosophical suicide is the acceptance of a religious answer to the question of absurdity, which is seen as completely negating reality, and is therefore just as destructive and detrimental as physical suicide. The only valid option given by Camus is an acceptance of the Absurd, acceptance of the fact that we seek meaning in a meaningless universe. The exemplar of this acceptance of the absurdity of life is the tragic Greek hero, Sisyphus.

In The Myth of Sisyphus, Camus draws from characters in literature and legend to demonstrate acceptance of the absurd, characters whom he believes derive from Sisyphus. Sisyphus was a king in Greek mythology who was known for his selfglorification and shrewdness, even in his interactions with the gods. King Sisyphus angered Zeus with his hubris. To punish Sisyphus for his excessive pride, Zeus forced him to roll a massive boulder up a hill for all of eternity only to have it roll

\footnotetext{
22 Albert Camus, The Myth of Sisyphus (HamishHamilton, 1955), 21.

${ }^{23}$ Ronald Aronson, "Albert Camus," Stanford Encyclopedia of Philosophy (Spring 2012 edition). Web. https://plato.stanford.edu/archives/spr2012/entries/camus/
} 
back down once the summit was almost reached. For as long as Sisyphus attempts the fruitless endeavor of rolling the boulder up the hill, his efforts will always be in vain. One might be inclined to pity the tragic hero for the endless, futile existence he has to endure. For Camus, this pity would be misplaced; why are you pitying a man for a meaningless existence when all of existence is meaningless? Sisyphus embodies the existential struggle all humans face: like Sisyphus, we live a life without meaning, without real purpose, and our attempt to find meaning in the world is just us rolling a boulder up a hill, only to have it come crashing back down. However, Sisyphus differs from us in that he knows his life is meaningless, he knows that no matter how hard he tries he will never reach the summit. Destined to fail, he endures. Sisyphus recognizes the absurdity of life, the absurdity of his own existence, and accepts it. He embraces the Absurd and in doing so revolts against it. As Camus says, "The struggle itself toward the heights is enough to fill a man's heart. One must imagine Sisyphus happy." 24 To revolt against the Absurd, to embrace the meaningless of life, is not only how one finds the will to continue living but how one finds the will to live passionately.

Thomas Merton, in his literary essays, confronts the question of the Absurd head on. Merton agrees with Camus's basic premise that the only authentic way to live is in revolt against the Absurd. But before we can understand Merton's thoughts on what it means to confront the Absurd, we will first have to understand how Merton believed people attempted to escape it. To do this, we will utilize the previous two thematic tropes, solitude and alienation. "If you seek to escape for its own sake and run away from the world only because it is (as it must be) intensely unpleasant, you will not find peace and you will not find solitude." ${ }^{25}$ We can read this quote by Merton through the lens of Camus: if one pursues solitude in order to escape from the intensely unpleasant world, or in other words, if one seeks meaning in solitude in a meaningless world, one will only find more meaninglessness. If solitude is pursued as a means to escape, as a tool used to escape the emptiness instead of embracing it, then it will lead to nothing but the same intense loneliness,

24 Ibid., 78.

25 Merton, Seeds, 69. 
the same "lucid anguish," 26 in the face of the Absurd that drove one to solitude in the first place. One must not attempt to evade the Absurd in solitude, but use that solitude to fully accept it.

Attempting to find meaning in the world is not done only in solitude, but in many other fashions, such as through the acquisition of material goods. Camus says, "A man wants to earn money in order to be happy, and his whole effort and the best of a life are devoted to the earning of that money. Happiness is forgotten; the means are taken for the end." ${ }^{27}$ Just as solitude is used as a means to find happiness and meaning, so too is capital. As with Marx, seeking happiness in money as a way to elude the Absurd leads only to the same lucid anguish one feels when one is alienated from one's being. Capital and solitude improperly pursued are ineffectively utilized to deter meaningless. This is all to say that, for Merton, people do not want to confront the Absurd. Instead, they live inauthentically because they have not found their authentic self, their true being in God. They live alienated from their being by pursuing meaning in a meaningless world.

For a person to confront and revolt against the Absurd, they must enter solitude, not to find meaning, but to embrace meaninglessness. When this emptiness is embraced by someone, they will be able to "affirm...the human love and solidarity and devotion to life which gives meaning to [their] existence."28 For Merton, one must empty oneself of all false meaning, of all idolatry with which one's being is falsely filled. Only after the futility and false hopes of the world are accepted will God fill your being with meaning and love. It is on this role of God where Camus and Merton depart from one another.

Camus, like most existentialists, was a devout atheist seeing no room for God in a world without meaning. For him, revolting against the Absurd is an entirely human practice. Merton, on the other hand, seeing meaning only coming from God. When we accept the emptiness of the world around us in our solitude, the revolt

\footnotetext{
26 Ibid., 42.

27 Camus, The Myth of Sisyphus, 66.

${ }_{28}$ Merton, Seeds, 42.
} 
against the Absurd is not actually of human origin, it is from God. According to Merton, it is by God's grace that we are allowed to recognize the emptiness of ourselves in the world and to find meaning in it. Therefore, rather than confronting the Absurd, one must accept the Absurd and allow God to fill one's being with meaning and love. In other words, living authentically is recognizing and accepting the absurdity of life and allowing God to grant you meaning in a meaningless world.

Thomas Merton was a continual searcher, never pausing in one place as he searched for answers. As academics, this is our life too. Never are we satisfied with the status quo, always pushing the boundaries of knowledge into uncharted territories, hoping we find an island before we drown in the waters of obscurity. But time and time again we find our land, our ground of knowledge for which we've searched so long for. Searching is what we do and searching is what he did.

Throughout his life, Merton was searching for himself, attempting to find some center, some ground from which he could confidently build his life, having never known stability. He was searching for authenticity and stability, finally finding it within a Catholic understanding deeply influenced by thinkers outside this tradition. Thomas Merton's thoughts on what it meant to lead an authentic life, to be authentic, were influenced undoubtedly by his Catholic beliefs, but also from a variety of secular sources. As with autobiographies, we have told a supposedly true story through the lens of self-chosen symbols. Solitude, the deep self, alienation, and the Absurd have been the hermeneutic tools employed to illuminate how Lionel Trilling, Karl Marx, and Albert Camus influenced the notion of authenticity within the works of Thomas Merton. For Merton, to live authentically meant to find one's Deep Self through the gift of Solitude so one can live a life fully in one's Being in order to give that Being to others; to live in a non-alienated life not in pursuit of worldly goods to escape the Absurd, but in a life that fully embraces it: the authentic life is to accept the wholeness we already are by the grace of God. "SIT FINIS LIBRI, NON FINIS QUAERENDI."29 "Here ends the book, but not the searching."

\footnotetext{
${ }^{29}$ Merton, The Seven Storey Mountain, 462.
} 


\section{Bibliography}

Aronson, Ronald. 2011. Albert Camus.

https://plato.stanford.edu/archives/spr2012/entries/camus/.

Camus, Albert. The Fall. New York City: Vintage Books, 1991.

. The Myth of Sisyphus and Other Essays. HamishHamilton, 1955.

Merton, Thomas. New Seeds of Contemplation. New York City: New Directions, 2007. . Seeds. Boston: Shambhala, 2002.

—. The Asian Journals of Thomas Merton. New York City: New Directions, 1975. . The Seven Storey Mountain. Orlando: Harcourt, Inc., 1998.

- The Sign of Jonas. Garden City: Image Books, 1956.

- The Way of Chuang Tzu. New York City: New Directions, 2010.

Trilling, Lionel. Sincerity and Authenticity. Cambridge: Harvard University Press, 1972. 